Tropical Journal of Pharmaceutical Research October 2020; 19 (10): 2115-2121

ISSN: $1596-5996$ (print); 1596-9827 (electronic) (C) Pharmacotherapy Group, Faculty of Pharmacy, University of Benin, Benin City, 300001 Nigeria.

\title{
Antimicrobial properties of bioactive compounds isolated from epidermal mucus in two Ray species (Dasyatis marmorata and Gymnura altavela)
}

\author{
Ali Uyan ${ }^{1 *}$, Cemal Turan ${ }^{1}$, Elif Ayse Erdogan-Eliuz², Mustafa Kemal Sangun ${ }^{3}$ \\ ${ }^{1}$ Molecular Ecology and Fisheries Genetics Laboratory, Faculty of Marine Sciences and Technology, Iskenderun Technical \\ University, 31220 Iskenderun, Hatay, ${ }^{2}$ Department of Food Technology, Technical Sciences Vocational School, Mersin \\ University, 33343, Mersin, ${ }^{3}$ Department of Chemistry, Faculty of Arts and Sciences, Hatay Mustafa Kemal University, 31060, \\ Antakya, Hatay, Turkey
}

*For correspondence: Email: ali.uyan@yahoo.com; Tel: +90-535-6373437, +90-326-6141693; Fax: +90-326-6141877

Sent for review: 13 March 2020

Revised accepted: 21 September 2020

\begin{abstract}
Purpose: To investigate the occurrence and antimicrobial effects of certain biochemical compounds in the epidermal mucus secretions of fish and to demonstrate their potential for biomedical applications. Methods: Crude, aqueous, and acidic epidermal mucus samples were collected from live ray specimens. Gas chromatography and gas chromatography-mass spectrometry (GC/MS) analyses were performed to identify the biochemical compounds present in the mucus. The spectrophotometric broth microdilution method was used to determine the antibacterial and antifungal properties of the mucus extracts. The bacterial strains, Bacillus subtilis, Escherichia coli, Enterococcus faecalis, and Klebsiella pneumonia, were used for the tests, as well as the fungal strains, Candida parapsilosis and Candida albicans.

Results: GC/MS analysis revealed the presence of several hydrocarbon-derived compounds in the epidermal mucus of the two ray species. The acidic extract of $G$. altavela epidermal mucus produced a high MIC value, indicating the highest inhibitory effect of $8.64 \mu \mathrm{L}$ against $E$. coli, while the crude extract of $\mathrm{G}$. altavela epidermal mucus (41.13 $\mu \mathrm{L}$ against B. subtilis) was the least effective.

Conclusion: Epidermal mucus extracts, especially when acid-based, displays strong antimicrobial properties against all the tested pathogens. These findings suggest the plants possess some potential for the development of novel antimicrobial components for applications in medicine.
\end{abstract}

Keywords: Fish, Ray species, Epidermal mucus, Antimicrobial properties, Bioactive compounds

\begin{abstract}
This is an Open Access article that uses a funding model which does not charge readers or their institutions for access and distributed under the terms of the Creative Commons Attribution License (http://creativecommons.org/licenses/by/4.0) and the Budapest Open Access Initiative (http://www.budapestopenaccessinitiative.org/read), which permit unrestricted use, distribution, and reproduction in any medium, provided the original work is properly credited.
\end{abstract}

Tropical Journal of Pharmaceutical Research is indexed by Science Citation Index (SciSearch), Scopus, International Pharmaceutical Abstract, Chemical Abstracts, Embase, Index Copernicus, EBSCO, African Index Medicus, JournalSeek, Journal Citation Reports/Science Edition, Directory of Open Access Journals (DOAJ), African Journal Online, Bioline International, Open-J-Gate and Pharmacy Abstracts

\section{INTRODUCTION}

In fishes, the external body surface generally is covered by a mucus coat secreted by epidermal gland cells. The mucus layer differs significantly in density and viscosity among fish species, and it is essential for fishes in several respects. Goblet cells are the major components of the mucus layer. While all mucosal surfaces in fishes have multiple distinct and complicated mechanisms for defense against pathogenic diseases, the skin mucus functions as the 
primary barrier against pathogens and environmental stressors [1].

Mucus is the slimy and sticky secretion that consists of mucins and a mixture of other materials, such as inorganic salts, immunoglobulins, and water-suspended lipids that give it distinctive lubricating characteristics. The mucins can be described as viscous colloids comprised of bacteria, proteins, and water. Mucins contain a variety of immune-relevant compounds that are defined as inherent defense variables, including glycoproteins, glycosaminoglycans, pheromones, proteolytic enzymes, lectins, galectins, lysozymes, calmodulins, immunoglobulins, complements, Creactive proteins and antimicrobial peptides (AMP). Numerous other antimicrobial peptides also provide defense mechanisms for fish against possible pathogens and potential environmental risks [1,2].

A few studies have been carried out on the antimicrobial properties of fish epidermal mucus in ray species that include the common stingray (Dasyatis pastinaca) [3,4], sharpnose stingray (Himantura gerrardi) [4], and bigtooth river stingray (Potamotrygon cf. henlei) [5]. The three aforementioned studies also investigated the antimicrobial effects of epidermal mucus (acidic, crude, and aqueous extracts) of ray species against for both gram-positive and gram-negative bacterial strains, as well as against fungal strains.

Information about the antimicrobial properties and biochemical structures of fish epidermal mucus may help in developing antimicrobial drugs for therapeutic purposes. To the best of our knowledge, there have been no studies on antimicrobial properties of epidermal mucus obtained from the marbled stingray Dasyatis marmorata or the spiny butterfly ray Gymnura altavela. Also, there is an insufficient number of studies about GC/MS analysis of fish mucus in the literature. Consequently, the present study aimed to isolate biological compounds of the epidermal mucus of Dasyatis marmorata and Gymnura altavela and to determine the antimicrobial effects of their epidermal mucus extracts.

\section{EXPERIMENTAL}

\section{Collection of fish epidermal mucus samples}

Epidermal mucus was separated from the dorsal body surface of the fish with a sterile plastic spatula. Mucus was not collected from the ventral sides of the fish to avoid contamination by intestinal and urinogenital excretions [6]. A pooled sample of $50 \mathrm{~mL}$ of mucus was collected from each ray species and put into a sterile Falcon tube per species. The samples were stored in a bag filled with ice for transport to the laboratory and then stored at $-30{ }^{\circ} \mathrm{C}$ in the laboratory pending further analysis.

\section{Preparation of fish epidermal mucus extracts}

Crude extracts of epidermal mucus were prepared according to the method described by Mat Jais et al [7]. Initially, $10 \mathrm{~mL}$ of mucus was transferred to ten Eppendorf tubes in equivalent quantities and centrifuged at $5000 \mathrm{rpm}$ for 10 minutes. Then the obtained supernatant phase was stored at $4{ }^{\circ} \mathrm{C}$ in a refrigerator for antimicrobial assays.

The aqueous extract of epidermal mucus was prepared according to the process of Tyor \& Kumari [8]. Initially, $10 \mathrm{~mL}$ of mucus was transferred to each of ten Eppendorf tubes in equivalent quantities and was mixed with an equal amount of sterilized physiological saline solution $(0.85 \% \mathrm{NaCl})$ and centrifuged at 5000 rpm for 5 minutes. Then the supernatant phase was kept at $4{ }^{\circ} \mathrm{C}$ in a refrigerator for antimicrobial assays.

The acidic extract of epidermal mucus was prepared as described by Subramanian et al [2]. Initially, $30 \mathrm{~mL}$ of fish mucus was added to $30 \mathrm{~mL}$ of $3 \%$ acetic acid and heated for 5 minutes in boiling water. Then, the acid-mucus mixture was then cooled in the icebox and homogenized. The mixture was centrifuged at $18000 \mathrm{~g}$ and $4{ }^{\circ} \mathrm{C}$ for 35 minutes. Then the resultant supernatant liquid was purified through a $0.22-\mu \mathrm{m}$ filter syringe. Finally, the obtained elutes were stored in a refrigerator at $4{ }^{\circ} \mathrm{C}$ for antimicrobial assays.

The hexane extraction method was chosen to separate the volatile compounds from the epidermal mucus for GC/MS analysis using the modified protocol of Christy-Shaila et al [9]. The mucus sample $(2 \mathrm{~mL})$ and hexane $(2 \mathrm{~mL})$ were added to the sample tube and extracted with an ultrasonic bath (1 $\mathrm{min}$.) and vortex (1 $\mathrm{min}$.). The hexane phase was separated from the water after standing 30 minutes under laboratory conditions. The hexane extract was filtered with a $0.45-\mu \mathrm{m}$ syringe filter to prepare it for GC/MS analysis.

\section{Bradford assay}

Total protein concentration in the crude extracts of epidermal mucus was determined based on the method introduced by Bradford [10] with 
bovine serum albumin (BSA) as the standard (Bio-Rad). Briefly, $1 \mathrm{~mL}$ of epidermal mucus sample was mixed with $1 \mathrm{~mL}$ of Bradford reagent, incubated at ambient temperature for 10 min and read at $595 \mathrm{~nm}$ with a Thermo Evolution 160 UV-VIS spectrophotometer. A standard curve ranging from $0-2.0 \mu \mathrm{g} / \mathrm{mL}$ was generated with absorbance at $595 \mathrm{~nm}$, and the protein content of the epidermal mucus was calculated for each ray species.

\section{GC-MS analysis}

A mucus sample of $1.0 \mu \mathrm{L}$ was injected splitlessly using a Finnigan-Trace GC/MS unit with an autosampler. The capillary column used was Zebron ZB-5 (5\% phenyl-95\% dimethylpolysiloxane), $0.25 \mathrm{~mm}$ i.d. x $60 \mathrm{~m}$, film thickness $0.25 \mu \mathrm{m}$. Helium was used as the carrier gas at a stable flow rate of $1.0 \mathrm{~mL} / \mathrm{min}$. The inlet temperature was set at $260{ }^{\circ} \mathrm{C}$. The column temperature was first kept at $70{ }^{\circ} \mathrm{C}$ for 1 minute, then increased to $260{ }^{\circ} \mathrm{C}$ at $6{ }^{\circ} \mathrm{C} / \mathrm{min}$, and finally increased to $300{ }^{\circ} \mathrm{C}$ at $25{ }^{\circ} \mathrm{C} / \mathrm{min}$, where it was kept for 5 minutes. The column effluent was introduced into the MS ion source at $230{ }^{\circ} \mathrm{C}$.

The mass spectrometer was run in the electron impact (El) mode at $70 \mathrm{eV}$. Data was acquired in the full scan mode from 50 to $550 \mathrm{~m} / \mathrm{z}$, with the scan time being $0.5 \mathrm{sec}$. Data analysis was performed using total ion count (TIC) for compound recognition and quantification. The components' spectra and the database of spectra of the known components kept in the GC/MS library were compared. Quantitative determination was performed on the basis of peak area integration.

\section{Preparation of microbial strains}

The antimicrobial effects of acidic, crude, and aqueous extracts of the two ray species were investigated by the spectrophotometric broth microdilution method. Four bacterial strains-two gram-negative bacteria, Escherichia coli (ATCC 25293) and Klebsiella pneumonia, and two grampositive bacteria, Bacillus subtilis (ATCC 6633) and Enterococcus faecalis-as well as two fungal strains, Candida albicans and $C$. parapsilosis, were used to investigate antimicrobial activities of the mucus extracts. Test microorganisms were inoculated with $4 \mathrm{~mL}$ of Tryptic Soy Broth for the bacteria and $4 \mathrm{~mL}$ of Sabouraud Dextrose Broth for the yeasts. Both batches were incubated at $37^{\circ} \mathrm{C}$ for 24 hours. According to $0.5 \mathrm{McF}$ arland standard turbidity $\left(\approx 10^{4}\right.$ for bacteria and $\approx 10^{3}$ for yeasts $)$, the microorganism suspensions were prepared after one day of incubation and were kept at $+4{ }^{\circ} \mathrm{C}$ for use in spectrophotometric broth microdilution experiments. Ampicillin and Fluconazole were used as positive controls for bacteria and yeasts, respectively.

\section{Screening of fish epidermal mucus extracts for antimicrobial properties}

The method of microbroth dilution was used to determine the minimum inhibitory concentration (MIC), the lowest concentration of analyzed substances that prevents the growth of $99.9 \%$ of microorganisms, in according with the guideline of the U.S. National Committee for Clinical Laboratory Standards. After a $50 \mu \mathrm{L}$ portion of Mueller Hinton Broth (MHB) solution had been poured into each of the first-order wells of a 96well microplate, a $100-\mu \mathrm{L}$ portion of extract was added to each well. Then twofold serial dilutions of extracts were made to produce a final diluted sample concentration of $0.19 \mu \mathrm{L}$. Finally, $5 \mu \mathrm{L}$ of each microorganism was added into the wells. The same procedure was performed for the antibiotics. After all 96-plates had been incubated for 24 hours at $37{ }^{\circ} \mathrm{C}$, spectrophotometric analysis was performed at $600 \mathrm{~nm}$ for bacteria and $415 \mathrm{~nm}$ for yeasts to measure turbidity.

\section{Data analysis}

The MIC was calculated by using Microsoft Excel 2013 computer software. The experiment was repeated at least three times, and the SPSS one-way ANOVA Tukey test was performed separately for MICs. The results were recorded as mean \pm SEM (standard error of the mean).

\section{RESULTS}

\section{Protein concentration}

On the basis of the seven-point standard calibration curve, ranging from $0-2 \mathrm{mg} / \mathrm{mL}(\mathrm{y}=$ $\left.0.5158 x+0.0845 ; R^{2}=0.9554\right)$, the total protein concentration of epidermal mucus was 4.43 $\pm 0.08 \mathrm{mg} / \mathrm{mL}$ for $D$. marmorata and $4.75 \pm 0.08$ $\mathrm{mg} / \mathrm{mL}$ for $\mathrm{G}$. altavela.

\section{Bioactive compounds}

Gas chromatography-mass spectrometry analysis, using hexane solution, was carried out on the epidermal mucus of two ray species. In the biochemical analysis of $D$. marmorata and $G$. altavela epidermal mucus, sixteen and fourteen compounds were identified, respectively. The major bioactive compounds in the mucus of $D$. marmorata were identified as 2-Isopropyl-5methyl-1-heptanol (10.04\%), 2-tert-Butyl-4- 
isopropyl-5-methylphenol (7.95\%), docosane $(7.98 \%)$, and dodecanoic acid $(15.76 \%)$. For the mucus of $G$. altavela, they were 1-nonene (8.13\%), 2-Isopropyl-5-methyl-1-heptanol (12.24\%), 2-Hydroxy-3-phenyl-2H-1-benzopyran $(11.83 \%)$, eicosane $(14.25 \%)$, and dodecanoic acid $(21.37 \%)$. The chromatograms of the GC/MS profile for each mucus are given in Figures 1 and 2. The peaks in the chromatogram were incorporated and then compared with the database spectra of the known components in the GC/MS library. Tables 1 and 2 show the results of GC/MS analysis of epidermal mucus.

The MIC values of acidic (DmAC), crude (DmCR) and aqueous (DmAQ) mucus extracts of $D$. marmorata, and acidic (GaAC), crude (GaCR) and aqueous (GaAQ) mucus extracts of $G$. altavela are summarized in Table 3 . The values, after incubation with microorganisms for $24 \mathrm{~h}$, ranged from 8.64 to $41.13 \mu \mathrm{L}$ for the tested pathogens $(n=18)(P<0.05)$. In general, all extracts below $50 \mu \mathrm{L}$ showed antimicrobial properties. The most effective MIC value was $8.64 \mu \mathrm{L}$ for $\mathrm{GaAC}$ extract against $E$. coli, followed by those of DmAC extract against $K$. pneumoniae (8.99 $\mu \mathrm{L})$, GaAC extract against $K$. pneumoniae $(9.01 \mu \mathrm{L})$, DmAC extract against $E$. coli $(9.30 \mu \mathrm{L})$, and $\mathrm{GaAC}$ extract against $B$. subtilis $(9.40 \mu \mathrm{L})$.

The antimicrobial activity of the DmAQ extracts against $C$. parapsilosis ( $\mathrm{MIC}=38.05 \mu \mathrm{L}$ ) was lower and statistically different from those of other extracts (DmAC, DmCR, GaAC, GaCR, and $\mathrm{GaAQ})(P<0.05)$, as shown in Table 3.

Table 1: Chemical compounds of $D$. marmorata epidermal mucus identified via GC/MS

\begin{tabular}{lccccl}
\hline No. & $\begin{array}{c}\text { Retention } \\
\text { time }\end{array}$ & $\begin{array}{c}\text { Peak area } \\
(\%)\end{array}$ & $\begin{array}{c}\text { Molecular } \\
\text { weight }\end{array}$ & $\begin{array}{c}\text { Molecular } \\
\text { formula }\end{array}$ & Name \\
\hline 1 & 16.52 & 7.45 & 200 & $\mathrm{C}_{13} \mathrm{H}_{28} \mathrm{O}$ & Isotridecanol \\
2 & 16.71 & 10.04 & 172 & $\mathrm{C}_{11} \mathrm{H}_{24} \mathrm{O}$ & 2-Isopropyl-5-methyl-1-heptanol \\
3 & 16.89 & 4.58 & 140 & $\mathrm{C}_{10} \mathrm{H}_{20}$ & 1,2,3,5-tetramethylcyclohexane \\
4 & 19.88 & 2.00 & 198 & $\mathrm{C}_{14} \mathrm{H}_{30}$ & Dodecane \\
5 & 20.55 & 3.17 & 198 & $\mathrm{C}_{14} \mathrm{H}_{30}$ & Tridecane \\
6 & 21.04 & 7.95 & 206 & $\mathrm{C}_{14} \mathrm{H}_{22} \mathrm{O}$ & 2-tert-Butyl-4-isopropyl-5- \\
& & & & & methylphenol \\
7 & 21.47 & 7.98 & 310 & $\mathrm{C}_{22} \mathrm{H}_{46}$ & Docosane \\
8 & 21.70 & 7.47 & 214 & $\mathrm{C}_{14} \mathrm{H}_{30} \mathrm{O}$ & 2-Hexyl-1-octanol \\
9 & 21.90 & 5.79 & 186 & $\mathrm{C}_{12} \mathrm{H}_{26} \mathrm{O}$ & 1-Octanol \\
10 & 23.26 & 15.76 & 242 & $\mathrm{C}_{15} \mathrm{H}_{30} \mathrm{O}_{2}$ & Dodecanoic acid \\
11 & 24.69 & 4.25 & 366 & $\mathrm{C}_{26} \mathrm{H}_{54}$ & Octadecane \\
12 & 25.24 & 3.29 & 242 & $\mathrm{C}_{16} \mathrm{H}_{34} \mathrm{O}$ & 1-Decanol \\
13 & 25.48 & 4.88 & 380 & $\mathrm{C}_{27} \mathrm{H}_{56}$ & Heptacosane \\
14 & 25.75 & 5.98 & 266 & $\mathrm{C}_{19} \mathrm{H}_{38}$ & 1-Nonadecene \\
15 & 26.13 & 5.79 & 294 & $\mathrm{C}_{21} \mathrm{H}_{42}$ & 10-Heneicosene \\
16 & 26.33 & 3.60 & 490 & $\mathrm{C}_{35} \mathrm{H}_{70}$ & 17-Pentatriacontene \\
\hline
\end{tabular}

Table 2: Bioactive compounds of $G$. altavela epidermal mucus identified via GC/MS

\begin{tabular}{lccccl}
\hline No. & $\mathbf{R T}$ & $\begin{array}{c}\text { Peak Area } \\
(\%)\end{array}$ & $\begin{array}{c}\text { Molecular } \\
\text { weight }\end{array}$ & $\begin{array}{c}\text { Molecular } \\
\text { formula }\end{array}$ & Name \\
\hline 1 & 15.13 & 2.24 & 184 & $\mathrm{C}_{13} \mathrm{H}_{28}$ & Undecane \\
2 & 15.31 & 2.38 & 212 & $\mathrm{C}_{15} \mathrm{H}_{32}$ & Pentadecane \\
3 & 16.53 & 8.13 & 168 & $\mathrm{C}_{22} \mathrm{H}_{46}$ & 1-Nonene \\
4 & 16.72 & 12.24 & 172 & $\mathrm{C}_{11} \mathrm{H}_{24} \mathrm{O}$ & 2-Isopropyl-5-methyl-1-heptanol \\
5 & 21.05 & 11.83 & 224 & $\mathrm{C}_{15} \mathrm{H}_{12} \mathrm{O}_{2}$ & 2-Hydroxy-3-phenyl-2H-1-benzopyran \\
6 & 21.17 & 4.63 & 214 & $\mathrm{C}_{14} \mathrm{H}_{30} \mathrm{O}$ & 2-Hexyl-1-octanol \\
7 & 21.72 & 14.25 & 282 & $\mathrm{C}_{20} \mathrm{H}_{42}$ & Eicosane \\
8 & 23.27 & 21.37 & 242 & $\mathrm{C}_{15} \mathrm{H}_{30} \mathrm{O}_{2}$ & Dodecanoic acid \\
9 & 25.26 & 4.18 & 258 & $\mathrm{C}_{16} \mathrm{H}_{34} \mathrm{~S}$ & tert-Hexadecanethiol \\
10 & 26.35 & 4.65 & 172 & $\mathrm{C}_{11} \mathrm{H}_{24} \mathrm{O}$ & 2-Isopropyl-5-methyl-1-heptanol \\
11 & 29.87 & 3.25 & 366 & $\mathrm{C}_{26} \mathrm{H}_{54}$ & Octadecane \\
12 & 30.10 & 3.58 & 380 & $\mathrm{C}_{27} \mathrm{H}_{56}$ & Heptacosane \\
13 & 33.24 & 3.98 & 314 & $\mathrm{C}_{20} \mathrm{H}_{42} \mathrm{O}_{2}$ & 2-Octadecyloxyethanol \\
14 & 36.43 & 3.29 & 578 & $\mathrm{C}_{16} \mathrm{H}_{50} \mathrm{O}_{7} \mathrm{Si}$ & Octasiloxane \\
\hline
\end{tabular}


Uyan et al

Table 3: MIC values of epidermal mucus extracts, determined by the spectrophotometric microdilution method

\begin{tabular}{|c|c|c|c|c|c|c|}
\hline \multirow{2}{*}{$\begin{array}{l}\text { Extract } \\
(\mu \mathrm{l})\end{array}$} & \multicolumn{6}{|c|}{ MIC + SEM* } \\
\hline & E. coli & $\begin{array}{c}K . \\
\text { pneumoniae }\end{array}$ & B. subtilis & E. faecalis & C. albicans & $\begin{array}{c}\text { C. } \\
\text { parapsilosis }\end{array}$ \\
\hline DmAC & $9.30^{a} \pm 0.08$ & $8.99^{b} \pm_{0.5}$ & $10.23^{b} \pm 0.1$ & $9.19^{b} \pm_{0.06}$ & $9.57^{\mathrm{a}} \pm 0.2$ & $9.77^{b} \pm 0.3$ \\
\hline DmCR & $12.78^{\mathrm{a}} \pm 2.9$ & $14.22^{\mathrm{b}} \pm 5.6$ & $14.69^{\mathrm{b}} \pm 3.5$ & $24.17^{b} \pm 9.1$ & $15.53^{a} \pm 2.3$ & $9.81^{\mathrm{b}} \pm 0.1$ \\
\hline DmAQ & $37.03^{\mathrm{a}} \pm 24.2$ & $19.02^{\mathrm{b}} \pm 3.7$ & $22.15^{\mathrm{b}} \pm 6.6$ & $16.54^{\mathrm{cb}} \pm 5.2$ & $20.60^{a} \pm 4.06$ & $38.05^{\mathrm{a}} \pm 15.2$ \\
\hline $\mathrm{GaAC}$ & $8.64^{a} \pm_{0.1}$ & $9.01^{b} \pm_{0.1}$ & $9.40^{b} \pm 0.1$ & $9.13^{\mathrm{b}} \pm_{0.2}$ & $9.40^{\mathrm{a}} \pm 0.01$ & $9.44^{b} \pm 0.1$ \\
\hline GaCR & $18.97^{\mathrm{a}} \pm 2.5$ & $27.84^{\mathrm{ab}} \pm 3.3$ & $41.13^{\mathrm{ab}} \pm 8.9$ & $23.26^{b} \pm 6.0$ & $21.99^{a} \pm 17.8$ & $16.92^{\mathrm{b}} \pm 7.6$ \\
\hline $\mathrm{GaAQ}$ & $22.58^{\mathrm{a}} \pm 0.02$ & $14.88^{\mathrm{b}} \pm_{4.1}$ & $16.97^{\mathrm{b}} \pm 6.3$ & $16.16^{b} \pm_{2.5}$ & $10.86^{a} \pm 0.9$ & $21.39^{\mathrm{ab}} \pm 7.6$ \\
\hline $\begin{array}{l}\text { Ampicillin } \\
(\mu \mathrm{g} / \mathrm{mL})\end{array}$ & $16 \pm 0.06$ & $8.99^{b} \pm 0.5$ & $32 \pm 0.4$ & $32 \pm_{0.3}$ & - & - \\
\hline $\begin{array}{l}\text { Fluconazole } \\
(\mu \mathrm{g} / \mathrm{mL})\end{array}$ & - & - & - & - & $128 \pm 3.5$ & $128 \pm_{0.5}$ \\
\hline
\end{tabular}

${ }^{*}$ SEM: Standard error of the mean. Mean MICs are expressed with the standard deviation ( \pm ) and significance level (ANOVA, $P<0.05$, Tukey's test). Values on the same column with different superscript letters differ statistically from the 0.05 probability

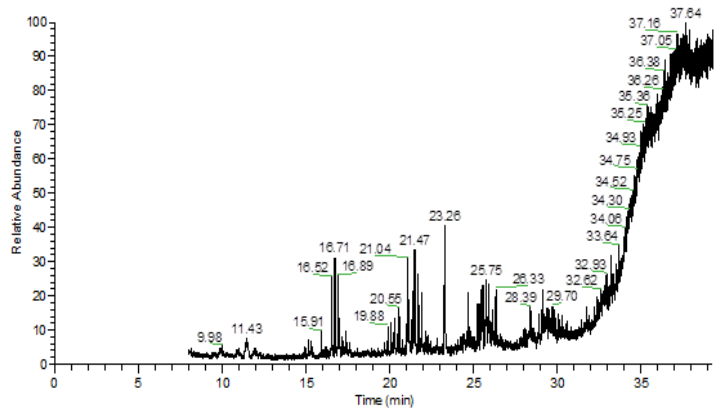

Figure 1: GC/MS chromatogram of D. marmorata epidermal mucus

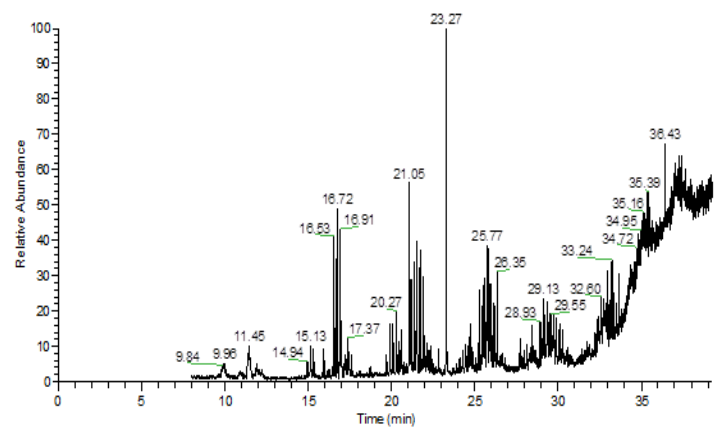

Figure 2: GC/MS chromatogram of $G$. altavela epidermal mucus

\section{DISCUSSION}

This study examines the total protein concentrations, bioactive compounds, and antimicrobial activities of the epidermal mucus secretions of Dasyatis marmorata and Gymnura altavela. Previous studies have suggested that inhibitory functions and biochemical structures of the mucus of various fishes may change on the basis of various pathogens, inter- and intra-fish species diversity, ecological and physiological conditions, nutritional impact, environmental stresses such as changes in water $\mathrm{pH}$ or salinity, and the growth and maturity of the fishes. Even differences in laboratory protocols or conditions of sample storage may affect those characteristics $[2,11,12]$.

Total protein analysis showed a higher protein concentration for the analyzed epidermal mucus of the two ray species when compared to several studies on other fish species [2,13-15]. The protein content in the epidermal mucus may vary based on various stress factors of fishenvironmental factors (e.g. water quality, i.e. the values of $\mathrm{DO}, \mathrm{CO}_{2}$, ammonia, and $\mathrm{pH}$ ), presence of contaminants, and differences between fish species. Subramanian et al [2] found that the mucus-producing cells in the epidermal and epithelial layers show difference among fish species, and therefore, they may affect the composition of mucus.

GC/MS analysis revealed that the hexane extracts of the epidermal mucus from each ray species contained numerous volatile compounds. Among the identified major compounds in the epidermal mucus of $D$. marmorata, antimicrobial activities were reported for the bioactive compound 2-isopropyl-5-methyl-1-heptanol [16] and the alkane docosane [17]. Antibacterial, antifungal, and antiviral properties have been observed in the saturated fatty acid dodecanoic acid [18]. The biological activity of 2-tert-Butyl-4isopropyl-5-methylphenol has not been clearly identified [19]. In the epidermal mucus of $G$. altavela, antibacterial and antifungal properties were found in the alkane 1-nonene [20], and anticancer and antimicrobial effects were reported for the alkane eicosane [21]. Similarly, 2-isopropyl-5-methyl-1-heptanol and dodecanoic acid were also observed as important bioactive compounds. No biological properties have been reported for 2-hydroxy-3-phenyl-2H-1- 
benzopyran to date. Christy-Shaila et al [9] analyzed biochemical components in the mucus of zebrafish (Danio rerio), and, similar to the results of this study, they found eighteen compounds, all of which were hydrocarbons.

Antimicrobial activity against all the test pathogens was also detected in the aqueous and crude extracts. The MIC results are at variance with previous studies on the aqueous mucus extracts of Pollachius virens, Gadus morhua, Labrus bergylta, Scophthalmus rhombus, Platichthys flesus and Solea solea against $B$. subtilis, E. coli, K. pneumoniae, and C. albicans [6], and with those of the crude and aqueous mucus extracts of Channa striatus against $B$. subtilis and $K$. pneumoniae [13]. The discrepancies in antimicrobial effects of the same types of epidermal mucus extracts obtained from various fish species may originate from structural differences in their excreted mucus.

As shown by the MIC values of the acidic mucus extracts in this study, strong antimicrobial effects were obtained against all the used pathogens in the range of $8.99-10.23 \mu \mathrm{g} / \mathrm{mL}$ for DmAC and 8.64-9.44 $\mu \mathrm{g} / \mathrm{mL}$ for GaAC. Those values show greater inhibitory effectiveness than was found in previous studies on acidic mucus extracts carried out on Oreochromis niloticus and Mystus nemurus against $E$. coli, $B$. subtilis and $K$. pneumoniae [14], Salvelinus fontinalis and Melanogrammus aeglefinus against E. coli [2], and Dasyatis pastinaca and Himantura gerrardi against $K$. pneumoniae, $E$. coli, and $C$. albicans [4]. They showed less effectiveness than did the studies of Myxine glutinosa mucus against $E$. coli [2], Potamotrygon cf. henlei against E. coli [5], and Channa striatus against $B$. subtilis and $K$. pneumoniae [13]. Therefore, specific acidic extracts that can be used as antimicrobial compounds need to be characterized as biomaterials for further biomedical examinations, especially against common pathogens.

This study includes preliminary results that may contribute to research in the use of biomaterials from the marine environment for biomedical applications. It is known that antibiotic resistance is among the most serious problems in medicine. Bacteria are among organisms that can reproduce and mutate very quickly. For that reason, prescribed antibiotic drugs tend to lose their effectiveness against certain bacterial species over time, and that causes problems in the treatment of some bacterial diseases [22]. Although increasing the dose increment of antibiotics may be evaluated as an option, the possible side effects have prompted researchers to look for biomaterial alternatives. Likewise, it is known that antifungal drugs are relatively unsafe and that effective antifungal drugs have yet to be developed due to the cellular similarity of fungi and mammals [23]. The azole group of antifungal agents, Fluconazole, Myconazole, Itraconazole, and Ketoconazole, has been used clinically. Because the side effects of those drugs, nephrotoxicity and hepatotoxicity, can include severe gastric distress [24], there remains a strong demand for the development of reliable antifungal drugs.

\section{CONCLUSION}

The most potent antimicrobial properties found in this study are exerted by the acidic mucus extracts of the two ray species. This shows that acid-soluble proteins may be key defense components against common pathogens. Further characterization of the antimicrobial substances may also give insight into possible human healthrelated applications as biomaterials, including uses such as antibacterial, antifungal, antiviral, anticancer, anti-hepatotoxic, antispasmodic, antirheumatic and antagonistic agents, as well as applications such as bulking agents, release media, protective coatings, lubricants, and emulsifiers.

\section{DECLARATIONS}

\section{Acknowledgement}

This study was derived from A Uyan's PhD Thesis. Thanks go to the Scientific and Technological Research Council of Turkey (no. TUBITAK-2211/C National Ph.D. Scholarship Program for Priority Areas) for support.

\section{Conflict of interest}

No conflict of interest is associated with this work.

\section{Contribution of authors}

We declare that this work was done by the authors named in this article and that all liabilities pertaining to claims relating to the content of this article will be borne by the authors. Ali Uyan and Cemal Turan performed the bibliographic research and drafted the manuscript. Elif Ayse Erdogan-Eliuz, and Ali Uyan analyzed the antimicrobial properties of fish mucus. Kemal Sangun, Ali Uyan, and Cemal Turan carried out GC/MS analysis. Cemal Turan and Ali Uyan contributed to all the writing and correction of the manuscript. All the authors reviewed the final 
version of the manuscript and contributed to the discussion of the data.

\section{Open Access}

This is an Open Access article that uses a funding model which does not charge readers or their institutions for access and distributed under the terms of the Creative Commons Attribution License (http://creativecommons.org/licenses/by/ 4.0) and the Budapest Open Access Initiative (http://www.budapestopenaccessinitiative.org/rea d), which permit unrestricted use, distribution, and reproduction in any medium, provided the original work is properly credited.

\section{REFERENCES}

1. Esteban MA. An overview of the immunological defenses in fish skin. ISRN Immunol 2012; 2012: 1-29.

2. Subramanian S, Ross NW, MacKinnon SL. Comparison of antimicrobial activity in the epidermal mucus extracts of fish. Comp Biochem Phys B 2008; 150(1): 85-92.

3. Fuochi V, Li Volti G, Camiolo G, Tiralongo F, Giallongo C, Distefano A. Antimicrobial and anti-proliferative effects of skin mucus derived from Dasyatis pastinaca (Linnaeus, 1758). Mar Drugs 2017; 15(11): 342.

4. Vennila $R$, Kumar $K R$, Kanchana $S$, Arumugam $M$, Vijayalakshmi S, Balasubramaniam, T. Preliminary investigation on antimicrobial and proteolytic property of the epidermal mucus secretion of marine stingrays. Asian Pac J Trop Biomed 2011; 1: 239-243.

5. Conceição K, Monteiro-dos Santos J, Seibert CS, Silva Jr. PI, Marques EE, Richardson M, Lopes-Ferreira M. Potamotrygon cf. henlei stingray mucus: Biochemical features of a novel antimicrobial protein. Toxicon 2012; 60(5): 821-829.

6. Hellio C, Pons AM, Beaupoil C, Bourgougnon N, Le Gal $Y$. Antibacterial, antifungal and cytotoxic activities of extracts from fish epidermis and epidermal mucus. International J Antimicrob Agents 2002; 20(3): 214-219.

7. Mat Jais AM, Matori MF, Kittakoop P, Suwanborirux $K$. Fatty acid composition in mucus and roe of haruan, Channa striatus, for wound healing. Gen Pharmacol 1998; 30(4): 561-563.

8. Tyor AK, Kumari S. Biochemical characterization and antibacterial properties of fish skin mucus of fresh water fish, Hypophthalmichthys nobilis. Int J Pharm Pharm Sci 2016; 8(6): 6-10.

9. Christy-Shaila R, Kathireswari P, Saminathan K. GC-MS Analysis of biochemical compounds present in the mucus of zebra fish (Danio rerio). IJRASET 2018; 6(5): 1109-1112.

10. Bradford M. A rapid and sensitive method for the quantitation of microgram quantities of protein using the principle of protein dye binding. Anal Biochem 1976; 72: 248-254.
11. Shephard KL. Mucus on the epidermis of fish and its influence on drug delivery. Adv Drug Deliv Rev 1993; 11(3): 403-417.

12. Blackstock $N$, Pickering $A D$. Changes in the concentration and histochemistry of epidermal mucous cells during the alevin and fry stages of the Brown trout Salmo trutta. J Zool 1982; 197: 463-471.

13. Wei OY, Xavier $R$, Marimuthu $K$. Screening of antibacterial activity of mucus extract of snakehead fish, Channa striatus (Bloch). Eur Rev Med Pharmaco 2010; 14(8): 675-681.

14. Rao V, Marimuthu K, Kupusamy $T$, Rathinam $X$, Arasu MV, Al-Dhabi NA., Arockiaraj J. Defense properties in the epidermal mucus of different freshwater fish species. Aquac Aquar Conserv Legis 2015; 8(2): 184-194.

15. Mahadevan G, Mohan K, Vinoth J, Ravi V. Biotic potential of mucus extracts of giant mudskipper Periophthalmodon schlosseri (Pallas, 1770) from Pichavaram, southeast coast of India. J Basic Appl Zool 2019; 80(1): 13.

16. Selvin J, Shanmughapriya S, Gandhimathi R, Kiran GS, Ravji TR, Natarajaseenivasan K, Hema TA. Optimization and production of novel antimicrobial agents from sponge associated marine actinomycetes Nocardiopsis dassonvillei MAD08. Appl Microbiol Biotechnol 2009; 83(3): 435-445.

17. Geetha DH, Jayashree I, Rajeswari M. GC-MS Analyses of bioactive compounds of ethanolic seed extract of Elaeocarpus serratus. Int J Pharm Pharm Res 2019; 11(1): 31-34.

18. Dayrit FM. The properties of lauric acid and their significance in coconut oil. J Am Oil Chem' Soc 2015; 92: 1-15.

19. Sangeetha C, Krishnamoorthy A S., Nakkeeran S, Ramakrishnan S, Amirtham D. Evaluation of bioactive compounds of Ophiocordyceps sinensis [Berk.] Sacc. against Fusarium spp. Biochem Cell Arch 2015; 15(2): 431-435.

20. Giwanon R, Thubthimthed S, Rerkam U, Sunthorntanasart T. Antimicrobial activity of terpinen-4ol and sabinene. TJPS 2000; 24(Suppl): 27.

21. Chuah XQ, Okechukwu PN, Amini F, Teo SS. Eicosane, pentadecane and palmitic acid: The effects in in vitro wound healing studies. Asian Pac J Trop Biomed 2018; 8(10): 490-499.

22. Povolo VR, Ackermann M. Disseminating antibiotic resistance during treatment. Science 2019; 364(6442), 737-738.

23. Numan M, Bashir S, Mumtaz R, Tayyab S, Rehman NU, Khan AL, Shinwari ZK, Al-Harrasi A. Therapeutic applications of bacterial pigments: a review of current status and future opportunities. 3 Biotech 2018; 8(4): 207.

24. Fukai $T$, Yonekawa $M$, Hou AJ, Nomura $T$, Sun HD, Uno J. Antifungal Agents from the Roots of Cudrania $c$ ochinchinensis against Candida, Cryptococcus, and Aspergillus Species. J Nat Prod 2003; 66(8), 1118-1120. 